\title{
EL SOBERANO ÓPTICO: LA FORMACIÓN VISUAL DEL PODER $^{1}$
}

\author{
Carlos Ossa \\ Universidad de Chile \\ anis626@yahoo.es
}

\section{RESUMEN / ABSTRACT}

El Estado Nacional se expandió durante el siglo XIX y principios del XX, no solo recurriendo a los fundamentos jurídicos e institucionales, también lo hizo consagrándose a proponer una serie de modelos visuales que regularan la vida social y pública. En este plano, las imágenes fotográficas cumplieron un rol mediador al unir una visión barroca del poder con una concepción positivista del orden. El resultado fue la construcción visual de la nación.

Palabras Clave: fotografía, poder, Estado, Barroco.

The Chilean State expanded during the XIX century and beginnings of the XX not only appealing to legal and institutional basis, but also by proposing a series of visual models that would regulate the social and public life. In this context, the photographic images played a intermediary role by uniting a baroque vision of power with a positivist conception of order. The result of that union was the visual construction of the nation.

KEYWORDS: photography, power, State, Baroque.

$1 \quad$ El presente artículo es resultado de la investigación "El ojo mecánico. Tecnologías visuales y estéticas políticas en Chile 1850-1930”, del proyecto FONDECYT n 1130654 concurso regular 2013. 


\section{ENCUADRE Y TERRITORIO}

...no puede haber una reflexión sobre la historia que no sea, al mismo tiempo, una reflexión sobre la fotografía.

Eduardo Cadava

En el Chile del siglo XIX, la construcción visual de la nación nace de un montaje epistémico - una red heterogénea de saberes, prácticas, teorías, símbolos y visiones de mundo- que diseñan metáforas de orden y destino, con las cuales el Estado disciplina a los pueblos en la noción unívoca de comunidad. Se trata de un proyecto fundacional que recurre a escenas barrocas, administración moderna y política conservadora. Reemplazados o excluidos los elementos étnicos, clasistas y plebeyos, emerge una nación excepcional que impone a la subjetividad una genealogía de la herencia, la propiedad y la sangre. Los pueblos son homologados con la idea del rebaño cristiano sujeto a la providencia y la razón de Estado, donde viven al amparo de una voluntad normativa. No se puede dejar el mundo abierto a la interpretación, deben ponerse marcas visuales que reduzcan lo inesperado o incontrolable. Así, lo popular soporta una discriminación explícita y, sin embargo, logra articularse como lema de unidad cuando los nuevos artefactos de visión lo capturan, militarizan y museifican. De igual modo, las elites convierten a las imágenes en el relato "natural" de su dominio utilizando los elementos de la artificialidad, la contingencia y la desproporción para presentar "una invención, un escenario creado para soportar la miseria, transfigurándola teatralmente en lujo, haciéndola maravillosa" (Echeverría 112) y exhibir su autoridad moral y política en distintos escenarios de autorreferencia, por ejemplo, en las ferias industriales inauguradas en $1869^{2}$. Los signos de la modernidad

2 La Exposición Nacional de Agricultura fue realizada con el objeto de dar a conocer la nueva economía de producción y exportación de trigo. Se trataba de reconciliar el modelo agrario de la hacienda con novedosas tecnologías de trabajo rural. En 1872, el intendente de Santiago, Benjamín Vicuña Mackenna, inaugura la Exposición de Artes e Industrias donde participaron varios artistas que fueron fundamentales en la elaboración pictórica del paisaje nacional, las costumbres y el naturalismo epocal: Pedro Lira, Antonio Smith, Manuel Antonio Caro, Onofre Jarpa, Nicanor Plaza, Ramón Subercaseaux, Pedro León Carmona, Thomas Somerscales y Cosme San Martín. A lo largo del siglo XIX y principios del XX las exposiciones $\mathrm{y}$ ferias giraron en torno al arte, la industria y la agricultura. 
atraen a todos los sectores y provocan demandas de bienestar, representación y reconocimiento histórico inéditos. El Estado Nacional desarrolla un complejo sistema de negociaciones simbólicas para enfrentar las tensiones de una sociedad conformada por la oligarquía vernácula, el corporativismo católico, el bajo pueblo y el liberalismo mercantil que viven de manera contradictoria y violenta el instante en que chocan las nuevas tecnologías con los valores tradicionales. Este mundo encuentra en la visualidad un modo de reconciliar el lenguaje colonial del poder, con la novedad fáctica de las imágenes y las quimeras identitarias. El Estado inventa un espacio estético-pedagógico urdido por la liturgia, el emblema, la fiesta y el examen panóptico del cuerpo. Sobre el particular, Julio Pinto y Verónica Valdivia señalan:

El énfasis que todos los gobiernos del siglo pusieron en la acción educacional respondió precisamente a esta constatación [...] Porque de lo que se trataba finalmente era de construir una nación no a partir del pueblo chileno realmente existente, sino de un pueblo abstracto y utópico (194).

Desde 1850, se va consolidando una cultura visual nacionalista, empeñada en una ilustración secular de la vida pública; una reforma de las pasiones y una regulación enciclopédica del territorio. Las imágenes deben subordinarse a una instancia que les otorgue dirección, control y efecto. El Estado se encarga de crear mecanismos de observación detallada del espacio (mapas); modelos inquisitivos de la mirada (policía); centros ceremoniales de la memoria (museos); cuantificación económica de los cuerpos (censos); significantes oculares de la obediencia (banderas-escudos), en suma, la presencia de un soberano óptico que instituye una tutela política entre poder, visualidad y población ${ }^{3}$. Hablamos de un Estado que organiza y aplica tecnologías del conocimiento con la finalidad de imaginarse a sí mismo como potencia redentora. En este plano, la fotografía ocupa un lugar destacado en la tarea de ser los ojos de un príncipe moderno preocupado de las taxonomías, los

\footnotetext{
Las imágenes son entendidas como medios para producir representaciones sociales de lugares y sujetos que concentran el poder o deben administrarlo. En este sentido, la Exposición del Coloniaje, inaugurada el 17 de septiembre de 1873, en el Palacio de los Gobernadores, fue un momento de restauración de los valores coloniales y la escenificación barroca de un pasado mayestático (carruajes, joyería, menaje, platería religiosa y setenta retratos de gobernadores) que declaraba a la nación el proyecto específico de una elite conservadora de tinte imperial, exhibiendo su riqueza particular y ancestros ilustres como eje fundacional.
} 
archivos y las fisiognomías propias de la vigilancia pastoral. Las imágenes fotográficas generan una singularidad estética y una masificación clasista exitosas al armonizar valores coloniales sobrevivientes con heráldicas de distinción modernizantes ${ }^{4}$. El lenguaje visual se impone en la ciudad mediante una alianza entre progreso y estética que vuelve inteligible un ethos ejemplar, basado en civilidad biológica, remodelaciones urbanísticas, paseos ciudadanos, normas de conducta, operaciones de higienización, electrificación del espacio público y espectáculo, pero sobre todo instalando un canon antropológico:

La fotografía, asociada en este período casi exclusivamente a la práctica retratística, cumplió un rol fundamental en el proceso de homogeneización social, construyendo la imagen de un 'ciudadano domesticado', previsible y, en consecuencia, indiferenciado; pero, sin duda alguna, consciente individualmente de formar parte de la élite social (Navarrete 15).

La existencia de unas claves visuales que más allá de los géneros han dado forma a cierta concepción de la realidad y protocolos de la mirada pueden considerarse puntos de partida de una lectura del Estado como sistema de representación y estructura estético-política. Bajo este supuesto la producción fotográfica y luego cinematográfica en Chile trabaja en la exhibición de un pueblo general -sin atributos muy específicos- que sirve de evidencia a la hegemonía lograda, sin embargo es un proceso transversal y abierto, que no concluye solo en fórmulas esteticistas o sociológicas, por el contrario interpela múltiples espacios unidos por dilemas visuales. Estos dilemas han estado presentes, de diverso modo, en la construcción de un poder cargado de imágenes, ritos y emblemas cuyas funciones son darle coherencia a la realidad social mediante tres ejes: un origen, la ley natural que lo identifica como posible y necesario; un fundamento, la historia compartida que valida un modo de vivir juntos; y una utopía, el destino trascendental dado a una comunidad para alcanzar su fin. Estas tareas nacen de una paradójica circunstancia, la comunidad no es posible, y se hace necesario inventarla, pues: "no es lo propio, sino lo impropio -o, más drásticamente, lo otro- lo

4 Mythos fue el primer local de retratos fotográficos abierto en Santiago en 1859 por Carlos Renard y Federico Leiva; la demanda principal del periodo se asocia con carte de visite. En los años del 1860 comienzan a popularizarse vistas y panoramas de paisajes documentales, antropológicos y artísticos. 
que caracteriza a lo común" (Esposito 31). Crear un espacio escénico a los tres ejes, lograr un máximo consenso, expresar valores complejos con efectos didácticos, convertir violencias materiales en imaginarios épicos, reunir a los individuos en torno a metas y obediencias deseadas se convierten en labores de la imagen estético-política.

...echando mano de liturgias y expresiones festivas que se hundían en el pasado, y resignificándolas en función de la nación que se quería construir, el liderazgo patriota finalmente encontró un terreno en que podía dialogar más fluidamente con los sujetos populares (...) $\mathrm{Y}$ aunque las fiestas y los ritos obviamente no lograron disimular las profundas grietas que seguían fracturando la sociedad chilena, ensanchadas todavía más por las nuevas que el proceso independentista había contribuido a instalar, sí pudieron, como en otro plano también la guerra, elaborar códigos compartidos de sentido, recuerdos y experiencias comunes, que con el correr de los años y las décadas irían cristalizando en referencias más o menos transversales de identidad (Pinto y Valdivia 205).

Las imágenes no son -exclusivamente- piezas de un intrincado sistema propagandístico, también una tecnología del poder que garantiza -como lo ha pensado Reinhart Koselleck- una prognosis, es decir un pensamiento prospectivo que mira de lejos. De esta manera el tiempo queda unido a una iconografía virtuosa que ofrece una versión anatómica del pasado, la validez social del presente y la cartografía del futuro; bajo este fondo vive el corpus visual de lo barroco y permite ese montaje entre un sistema simbólico "transparente" de la soberanía y una microfísica de imágenes dialécticas, anamórficas y enigmáticas. Es una tensión cultural y estética entre una visualidad excesiva y decorativa y un poder realista y ornamental que usan las imágenes para ensamblar o tejer el dictum de la ley al lenguaje, el cuerpo y la vida cotidiana. La fiesta patriótica, por ejemplo, es la escena privilegiada de un ensayo de comunidad, en ella el nacionalismo radical ambiciona constituirse en el significante vacío o la sintaxis de todas las culturas que conforman el relato de la identidad. "Existía conciencia sobre el poder de los símbolos, su accionar sobre la imaginación de los pueblos y su capacidad de incitar a la acción. La fiesta como un acto de 'psicología colectiva' aprovecha su influjo sobre una población sensible al poder de las imágenes tal como había sucedido durante todo el periodo hispano. Las autoridades apelaron como antaño, al reino de los sentidos" (Zaldívar y Sánchez 82). 
Lo político encuentra en la visualidad la solución a ese conflicto entre lo visible dado a los demás y lo invisible que se guarda como privativo y tiene la capacidad de mirar sin ser visto, pues funciona como sombra y clausura: "vigilancia de la mirada la cual pesa y organiza lo visible, efectivamente, desde el punto de vista focal de las composiciones plásticas barrocas, donde la historia humana se dispone como una suerte de ejecución teatral..." (De la Flor 136). Bajo esta lógica existe un concepto de representación que el Estado Nacional utiliza para documentar la relación entre gubernamentalidad (control de las poblaciones) e iconoclasia (unidad figurativa de lo público), es un momento de teatralidad que debe integrarse a los cuerpos como un valor estético. Esto es muy notorio en las fotografías y álbumes de guerra, de las familias patriarcales y de la ciudad junto a su adelanto arquitectónicoeconómico.

Las imágenes, juzgadas como un cristal de tiempo reflejan, deforman, trisan y rompen estos moldes y producen una fuerza narrativa en constante movilidad. Así, a pesar de la búsqueda de estereotipos y patrones nunca se consagra una rutina visual única. Múltiples problemas obligan a pensar la visualidad con sus improvisaciones, legados e invenciones como un proceso de significación provisorio, donde la lucha por el poder interpretativo exige entender la continua elaboración de modos de hacer, modos de sentir y modos de saber. De esta suerte la visualidad, en cuanto sistema de producción de metáforas icónicas sobre la soberanía justifica una representación doble del poder: una investidura sacrificial-pastoral y otra coercitiva-disciplinaria que proponen una síntesis contradictoria entre libertad y sometimiento ${ }^{5}$.

La construcción visual del país, la industria y el mercado se convierten en los contextos iconográficos a representar, en términos de una conquista a largo plazo, mientras el ciudadano, el trabajador y el consumidor encarnan a los sujetos modélicos cuyos signos de moralidad, sacrificio, libertad y respeto definen la identidad. El escenario político administrado por liberales y conservadores se nutrió de visiones positivistas, naturalistas, románticas y tecnocráticas que reclamaron la construcción de una imagen-país. Es posible advertir que entre los gobiernos de Manuel Bulnes (1841-1851) y José Joaquín Pérez (1861-1871) un campo visual se integra - exitosamente-a

5 El concepto moderno de soberanía, señala Walter Benjamin en El origen del Trauerspiel alemán, otorga al príncipe un supremo poder ejecutivo y la doctrina barroca se afianza en la discusión sobre el estado de excepción y la función del príncipe de evitarlo. 
delinear el rostro social de la elite y su proeza modernizadora ${ }^{6}$. A partir de la masificación de imágenes generada, no solo por el periódico, sino por la consagración de la fotografía impresa y el telégrafo, el escenario político de las administraciones de Federico Errázuriz Zañartu (1871-1876) a Germán Riesco (1901-1906) convierte a lo visual en mediación y reconocimiento social de grupos históricos negados y en exaltación tecno-nacionalista. La fusión entre las diversas tecnologías visuales y las estéticas políticas se transforma en el rasgo distinto de fines del siglo XIX y las tres primeras décadas del siglo XX, siendo el cine el imaginario colectivo que coloca en disputa nuevos lenguajes para observarse y viejos mitos para identificarse. En el transcurso de las renovaciones, síntesis, reapropiaciones y dominancias que el poder requiere para dar sentido al orden, someter la realidad a un principio rector y justificar el exceso o la arbitrariedad, la fotografía y el cine de registro realizaron operaciones visuales de alabanza, control, enseñanza y criminalización de grupos, imaginarios y valores. El uso de significantes icónicos y significados narrativos fue un modo de conformar la nación mediante:

a. reemplazar la hibridez de lo cultural por un código vertical de sujetos y signos legítimos, por ejemplo, la familia o el paisaje;

b. producir símbolos -institucionalizar valores patrióticos a través de su exhibición cotidiana y comunicacional- por ejemplo, los héroes, la bandera ${ }^{7}$, el presidente;

c. condensación de discursos - formalizar valores identitarios y promesas de futuro en estereotipos culturales trasmitidos como invención y herencia- por ejemplo, el museo, las ceremonias oficiales, los libros de efemérides.

Sin embargo, para darle coherencia a estas ideas -dentro de un régimen de visibilidad- se debe instaurar un espacio icónico que llamaremos realismo

6 La cámara oscura, introducida en el siglo XVIII por la Expedición de Malaspina, fue usada en el país a partir de 1829. La cámara lúcida en 1843 y el daguerrotipo en 1840; por su parte, el negativo de papel sensible se utiliza desde 1851.

Todos los actos fundacionales de las nuevas repúblicas -indica Natalia Majluf- se basaron en la jura de la bandera y eran la expresión del término de la monarquía. El pendón real que llevaba las insignias del rey y sus armas era trocado por la enseña nacional, el cuerpo del rey era sustituido por el emblema de la soberanía. La despersonificación del poder se lograba eliminando visualmente el cuerpo opresor. 
fundacional: la inauguración de un modo de organización visual del mundo que no tiene una concepción definida y estructurada, más bien, asume la ley mimética de la reproducción mecánica - propia del periodo- y la convierte en un sistema de veridicción, disciplina y estatus. Por lo mismo la noción de imagen política es ambigua, en esta primera parte, y no busca definir un relato militante específico, sino instaurar un nosotros vertical y dominante que se irá quebrando con el tiempo a partir de las rupturas estético-formales y político-ideológicas del poder. Cabe advertir que la construcción del Estado en América Latina obedece a un modelo excéntrico de modernidad (Sousa Santos) donde el barroco -como racionalidad política y estética- ha ocupado un lugar histórico complejo en la configuración de la sociedad y la cultura. Las metáforas (González García) que su ejercicio propone -el cetro, el emblema o la heráldica- confirman la articulación que la politología barroca establece entre imagen y poder (Maravall; De la Flor; Etienvre y Echeverría). Estas características motivan unos discursos sobre la autoridad (Ariza Canales 1995) que no se reducen a las estrategias formales de los procedimientos o las instituciones, sino que buscan imaginar a la comunidad (Esposito) incluida en el contrato jurídico del Estado y sus ceremonias. Existe, entonces, una trama de sentido donde las prácticas del poder fomentan un régimen escópico (Jay), una red de vigilancia sin cierre, plural y de múltiples conexiones. La idea de un ojo vigilante -paternal y punitivo- destinado a definir el límite de los vínculos sociales e individuales permite afirmar la existencia de una concepción barroca de la seguridad centrada en observar, controlar y proteger de sí misma a la subjetividad ${ }^{8}$. Desde el punto de vista genealógico podríamos decir que su huella parece hallarse en un ethos barroco que llena de simbología y exuberancia visual a la Razón de Estado que -a su vez- se apropia de la iconología cristiana para conformar el significado trascendental del gobierno. "El poder absoluto altomoderno se cifra en buena medida en estas figuraciones, revelando en ellas su naturaleza cultural, su calidad de artefacto, de constructo y jeroglífico visual de la superior esfera de dominación" (De la Flor 148). Pero ¿su fundamento a qué hace referencia? A unas fenomenologías visuales de desplazamiento, reconfiguración y creación de símbolos y contenidos

\footnotetext{
América Latina fue descubierta y conquistada por centros de poder débiles (España y Portugal) -según Boaventura de Sousa Santos- que suplieron la carencia de un régimen vertical con un sistema de exclusiones y violencias disciplinarias y con una economía visual orientada a la exageración, la monumentalidad y la extensión. En este plano, el barroco se convirtió en la subjetividad y en la estética del Estado.
} 
que puedan sostener las tradiciones y a su vez, fundar espacios nuevos de control, producción y relaciones sociales. Y ¿qué conseguiría este mundo de imágenes para el poder? Imaginar la historicidad fundacional de la lengua, establecer la demarcación jurídica del territorio y aplicar leyes comunes para sostener un orden siempre interpelado por lo inestable de su constitución. De acuerdo a lo anterior, la fuerza estética de las imágenes será usada para crear un nosotros libre de indistinción o vacuidad basado en un imaginario político que verifica la gloria y la aclamación como modos de reunir a los hombres y mujeres en torno a un ideal. Es lo que cree Giorgo Agamben cuando afirma que el modelo de gobierno moderno es una versión secularizada de la doctrina de la providencia. El Estado latinoamericano con sus retóricas del sacrificio y la vigilancia tiene un origen barroco. La importancia de la visibilidad encuentra en las representaciones mayestáticas de las fiestas, ceremonias, festejos y eventos institucionales el modo de hacer visible una soberanía construida por el deseo de trascendencia (el cristianismo) y de totalidad (razón de Estado). Entre ambos se configura la gubernamentalidad moderna que necesita la visión de guía y control. Aunque las prácticas estatales del siglo XIX y XX no tengan como referente directo lo anterior, subyace en su lógica y modelos un deseo de continuidad que hace de las imágenes un acontecimiento político fundamental.

La imagen no produce, en todo caso, una afirmación unívoca y lineal de la política -la contextualiza con aparatos de ficción y la construye con dispositivos de verosimilitud- creando un campo iconográfico cuya paradoja es: "...que el Estado requiere como coartada legitimadora de su naturalidad a la artificialidad de una identidad nacional fabricada" (Mandoki 87) siempre sujeta a observación y detalle. De esta forma se define una estructura visual cuyo trabajo consiste en organizar el mundo, dotarlo de dirección y justificarlo en los márgenes de una concepción del orden que posee una anotomía de lo visible (Gruzinski, Freedberg, Stephan).

Las imágenes fotográficas y cinematográficas producidas en la segunda mitad del siglo XIX en Chile proponen un modo de representación visual sobre lo público, su escenario temático y validación estético narrativa. Se trata de una sociedad que vive al amparo de un Estado oligárquico que descubre en las imágenes una nueva dimensión escénica destinada al ejercicio de la disuasión. Las imágenes dieron a la sociedad chilena un momento de reconciliación y de ruptura, pues ellas mostraron una nación (Alvarado, Báez y Mege; Martínez y Salgado) basado en la invisibilidad de la diferencia que actuó como paradigma republicano y, a la vez, fueron deteriorando el significando 
de un poder cerrado cuando la población exigió ser parte de esa visualidad que tenía una fuerza sorprendente: era capaz de incluir a todos en los contornos narrativos de un país que compensaba las desigualdades con homologaciones iconográficas. La cultura visual, que hemos indicado como articuladora de la imagen estético-política, conforma un conjunto de clichés, estereotipos y creaciones icónico-simbólicas cuya función cotidiana enlaza los signos de la nación y la modernidad con familias, paisajes, héroes, instituciones y excepcionalidad. El nosotros que las imágenes buscan representar da cuenta de un modelo de performatividad básico guiado por la convicción técnica de la reproducción de lo existente y la pretensión de trascendencia. Detener el movimiento de los cuerpos en una imagen y fijarlo a valores políticos y pedagógicos fue una manera de construir la kinésica de la nación. Así, cada individuo no representaba solo un índice de conciencia sino, por el contrario, era el fragmento público de una república aplicada a darle forma y estilo al gobierno de la población. La carga simbólica necesaria para ejecutar este disciplinamiento resultaba de la combinación de referentes barrocos como el águila, la cruz, el cetro junto con rúbricas neoclásicas como el mito solar, el culto adánico, la luz racional. Lo anterior daba anuncio a un espectáculo antropológico destinado a definir las relaciones entre mirada-cuerpo, seduccióntrabajo e instalaba los emblemas de una estética de oposiciones entre retratos de héroes, monumentos de mártires, pinturas de santos e imágenes opacas de religiosidad sincrética donde los tiempos se hacen mixtos y luchan por abrirse a múltiples efectos cromáticos, visuales, geométricos: en suma, el Estado Nacional mantiene en el centro de la modernidad - que aspira construir- una teología política rica en referencias visuales barrocas, es la organización de un tiempo que aprende a narrarse a sí mismo en la evidencia/secreto de sus actos, ceremonias y consagraciones.

\section{VER Y DESEAR}

La aparición de artefactos de ilusión dominó el escenario cultural decimonónico y generó una nueva relación material con el cuerpo y la subjetividad, ampliando los idiomas de la representación y dando al poder un glosario figuracional hasta ese momento desconocido. En este marco, ¿qué configuraciones visuales usó el Estado chileno para legitimar a sus elites y construir un relato de cohesión social? Para responder a esta pregunta es necesario comprender el modo en que una naciente cultura visual elabora los significantes y los 
símbolos de una dramaturgia del poder y la cultura (Canclini). El progreso es una meta oligárquico-liberal (Fernández, Góngora y Stuven) y se manifiesta como una fuerza regulativa y autorreferente que otorga a los sectores dominantes un grado de visibilidad que les permite controlar el reparto de lo sensible 9 (Rancière). De esta manera, los signos de autoridad no solo se expresan en leyes, contratos, constituciones, palabras, también en una serie de espectáculos y prácticas fotográfico-cinéticas que hablan de las clases, los mitos y los orígenes (Rodríguez, Rinke, Espinoza). Un momento explícito de la exuberancia -que arrastra todo hacia un presente óptico y soberano-fueron las celebraciones del centenario de la nación: "Las embajadas arribaban a la Estación Central, donde los esperaban lujosos carruajes y una batahola de fotógrafos. Los grandes protagonistas de esas ajetreadas jornadas fueron los miembros de la clase dirigente y sus pares de otros países. Aunque hubo fiestas populares, el pueblo de Santiago en general se limitó a interpretar el papel de espectador ávido de impresiones referentes a las vicisitudes y parafernalia de las ceremonias oficiales, y a la apariencia y aplomo de sus ilustres personajes. Resulta inapropiado distinguir los actos de Estado como la parada militar en el Parque Cousiño o la recreación histórica de la entrada del ejército patriota en traje de época a Santiago, de las celebraciones privadas como los bailes y banquetes organizados en mansiones particulares o en clubes privados. Después de todo, la élite que lideró los festejos identificaba el pasado de la nación con la historia de sus familias, y la gesta independentista con el heroísmo de sus antepasados. Entre sus representantes, el espíritu de exaltación patriótica solía confundirse con el orgullo del propio linaje. Hasta cierto punto, el Centenario constituyó por lo mismo, un asunto de competencia de las grandes familias" (Correa 43). Fue el instante de la mínima distancia entre nacionalismo y familia: una política de los retratos y las figuras exultantes, oblicuas y arcaicas reclamando el derecho a ser los propietarios del pasado y el futuro. Si el rey fue la imagen dominante en sellos, bustos y pinturas, la elite se nombrará a sí misma en fotografías y documentales para mostrar la declinación del aura

\footnotetext{
La fotografía y el cine documental son una "prosa del mundo" que trabajan en un doble sentido: ofrecen una idea de realidad que es inmanente y serena, y a la vez, móvil y contingente. De esta forma, la aproximación con el poder estatal implica una teoría crítica de las imágenes, capaz de describir las variantes que se han puesto en juego a la hora de elaborar la epistemología (la red de saberes, técnicas e historicidades) de la visualidad producida en el país.
} 
regia ${ }^{10}$ por la imposición del aura burguesa. Este punto no es menor, pues llenar el vacío que deja la muerte del soberano -su ausencia simbólica- se repara saturando la actualidad con el retrato de un grupo social cohesionado, único y heroico que reemplaza la subjetividad del príncipe -no su autoridad-con la conciencia moderna del sujeto. Así, la visualidad del poder no es la mera transcripción de objetos y gestos de dominio, es la transición de un modelo representacional a otro donde se mudan cosas y también se resignifican. El encuentro entre una tradición señorial y un mecanismo óptico moderno creó un efecto disonante, por un lado, los miembros de la oligarquía reaccionaron con sospecha y entusiasmo a la idea de exhibirse en formatos y superficies; por el otro, se apropiaron de los medios de visión para regularlos y hacer de ellos un acontecimiento de clase único y monumental. Los gestos de distinción, las señales de prestigio, el entusiasmo patriótico, la validación de modas y fiestas junto con las figuras militares, políticas y artísticas fueron consignadas como garantías de un gobierno justo e incuestionable. La autoimagen que el poder tenía de sí mismo, en el periodo que va desde la segunda mitad del siglo XIX a la primera del XX, puede describirse como tautológica, moralizante, pedagógica y ritual. Un criterio de superioridad, un modelo de conducta y una vida cívica, llena de teatralidad, en muchos casos exuberante y vacía, fueron elementos constantes para dar sitio a una mirada política. En torno a ella se reunió un grupo cerrado, la llamada Tribu de Judá, que convirtió sus fantasías familiares en una ilusión civilizatoria que encontraba en París, Londres o Madrid las claves de su legitimidad (Jocelyn-Holt, Barros y Vergara, Ossandón). La fotografía, en el siglo XIX realizó una importante tarea en la visibilidad de la cuna oligárquica, la ciudad flotante, la Guerra del Pacífico. El cine de registro, en el principio del siglo XX, propuso una estética incluyente que validó la relación indulgente entre pueblo y gobierno; en este plano, son significativos los registros cinematográficos realizados en torno a los funerales de presidentes, el crecimiento urbano, la diversión de clase, la infantilización de pueblo. La necesidad de certificar el tránsito de la Colonia

10 Revisar la obra de Louis Marin. Portrait of the King (traducción de Martha Houle). University of Minnesota Press, 1988. En ella se señala que la representación del poder absoluto se establece en tres dimensiones: jurídica tautológica -"el Estado soy yo"-; consagración eucarística -"este es mi cuerpo"- y mimética devocional -"ese es el césar, ese es el rey"-. Los tres momentos, aunque de manera excéntrica, participan de una escenificación visual del Estado en América Latina. Cada una recurre a una materialidad estética, estilos y formas, que nacen de la combinación, la yuxtaposición y la mezcla. 
a la República exigía un sistema de representaciones capaz de articular un campo intelectual, una política cultural y una institucionalidad jurídica. El conjunto debía expresarse en imágenes grandilocuentes, efectivas y didácticas.

El Estado se expandía haciendo uso de una racionalidad administrativa, pero debía capturar la obediencia y aceptación de sectores que no vivían en la letra y se sentían excluidos de los goces del progreso. Un poco antes que Víctor Daroche propusiera al Gobierno de Manuel Montt la elaboración de un álbum de las ciudades chilenas y con ello se justificara el rol de las elites en la conducción de un país actualizado y productivo, Johan Moritz Rugendas elaboraba para el Estado diversas imágenes de la "realidad", siendo el principal artífice de un mito corporal: el huaso. Metáfora de rudeza y encarnación pastoral de la figura terrateniente, idilio entre la sangre de la tierra y la propiedad ancestral. A modo de efigies, las naturalizaciones del paisaje, el abolengo y la fuerza física sirvieron para crear galerías de personajes que se transformarían, posteriormente, en los modelos usados por la fotografía y el cinematógrafo.

Hay una visualidad fundacional que se expande y consagra desmintiendo el carácter-estrictamente- letrado del período. Al respecto, Hernán Rodríguez nos recuerda: "Antes que el público pudiera retratarse mecánicamente, se había acostumbrado a asistir en Santiago o Valparaíso al espectáculo del Cosmorama que exhibía puertos de mar, batallas terrestres y navales, funciones sagradas, grandes metrópolis y paisajes escogidos en un juego de imágenes y proyecciones, estrenado en 1839 y anticipo de la magia fotográfica".

Intentar comprender que estrategias visuales fundaron un tiempo icónico, en una sociedad que no lograba conciliar las tensiones entre una modernización expansiva y un nacionalismo concentracionario, implica reconocer que los instrumentos de la percepción (Crary) sirvieron para consensos internos entre liberales y conservadores. Los instrumentos ayudaron a dar sistematicidad al poder, gracias a un flujo visual que lo volvía constante y construía la gráfica de las fortunas y los estereotipos de la dignidad. El dominio del espacio escénico no era total, en la medida en que las ciudades se convertían en zonas de contacto, la aparición de los rotos estimulaba pánicos atávicos (Grez y Pinto y Salazar) y deterioraba la paz veneciana conseguida al amparo del control total del Estado. La visibilidad se transformó en un tema importante, a la hora de determinar quiénes tenían derecho a la imagen, pues los cuerpos de los individuos portaban en sus señales físicas los orígenes y los desvíos de la ley, la lengua y el territorio. Asimismo, el documental logró dar a la hegemonía un nuevo carácter: la estetización de lo social. Hasta mediados de 1930, el 
Estado orienta la fisonomía de la sociedad desde una iconografía enérgica y modélica que trasmite valores conservadores junto con optimismos técnicos (Baéz; Crouchet y Piñeiro; Vega; Andermann y Rowe). A causa de lo anterior, el cine cumple en la esfera chilena moderna distintas tareas de recaudo, fuga y transacción. Debe preservar viejas patrias simbólicas, reemplazar de modo continuo valores efímeros, anticipar modelos de temor y bienestar. Estas dimensiones requieren organizar visualmente el espacio, inventar gramáticas y socializar lenguajes para articular lo heterogéneo, disímil y extraño, así la vigilancia aparece, pero también se reestructuran las prácticas humanas en torno a la formalización estético-política de la mirada y su compaginación por la reproductibilidad técnica. La búsqueda de un lugar visual permitió, a quienes administraban el Estado, definían la cultura y controlaban la vida cotidiana, hallar y crear los argumentos históricos de una trascendencia irrefutable: "El retrato oficial representa la imposición visual y moral de un sujeto que, en complicidad con el fotógrafo, ha dispuesto para sí y los demás la manera de llevar el poder" (Riera 28).

Una de las cuestiones fundamentales que se refuerza con este proceso es la idea de la ascendencia moral, la justificación de una superioridad inefable que permitía tener el monopolio estatal y entenderlo como un derecho natural originario. Definir este principio, celebrar su consistencia y poderío, trasmitirlo al resto de la sociedad fue una de las tareas de la novedosa cultura visual que hemos mencionado. El material fotográfico y fílmico se consagró a narrar la aparición de un cuerpo y una subjetividad ya integrados a las tecnologías de lo visible cuya originalidad se hizo manifiesta por la combinación de materialidades diferentes: una serie de gestualidades barrocas dedicadas a exhibir el orden como natural y sobrenatural ${ }^{11}$; diversas rutinas festivas que colonizan el espacio público e imponen un discurso visual iconoclasta; la

$11 \quad$ El poder reflexiona su desmesura en el barroco, encuentra en él una teoría política que justifica su exceso y el peligro del mismo. Entiende que detrás de la norma se encuentra el fantasma de la tragedia e inventa una serie de reglas, compromisos y conceptos que ayuden a mantener el gobierno en una mano sólida y absoluta. Por ello, las decisiones del príncipe son irrefutables, indiscutibles, de las mismas depende la estabilidad y la ventura económica. En cierta medida la estética del Estado Nacional descansa en una política barroca de la norma y la excepción, de lo racional y lo desmesurado, de la libertad concedida y de la reclusión impuesta. La imagen, entonces, no viene a ser la ilustración de los hechos, sino el mapa de los saberes y las pasiones que construyeron la subjetividad moderna y su paradójica forma: retazos de tiempos, tradiciones, visualidades, miedos y razones gestando una soberanía. 
circulación pedagógica de los mitos identitarios y sus referentes biológicos dispuestos a fijar en la mirada colectiva el lugar de los justos.

Los eventos de la vida moderna, los espectáculos de una sociedad en transformación, los signos de estatus y la jerarquía de las emociones hicieron posible que objetos ópticos de diverso cuño confirmaran la idea de un país institucionalmente estable. El ferrocarril, los casinos, las fiestas patrias, los funerales, el paisaje, la arquitectura sintetizaron el flujo lumínico, la plegaria patriótica, el mito étnico y la apelación populista (Moraga; Morrison; Bisama) con los discursos políticos, las identidades simbólicas y los consensos económicos, en torno, a un nacionalismo que se imaginaba íntegro, sin fisuras y totalizante. El Estado, entonces, hace el esfuerzo de proponer una nación, una comunidad y una modernidad singulares, marcadas por imágenes de orden, decencia, autoridad y progreso. Así, en los primeros treinta años de la historia moderna de Chile, el cine inventó un movimiento visual que no es reductible solo a patrimonio y memoria, pues dejó la constancia a veces anecdótica-de una sociedad en conflicto político y simbólico permanente. Pero durante el siglo XIX la fotografía justificó la mitopoesis de la occidentalización de la memoria, es decir, la legitimación de la elite de ser la garante estética de la nación al inventarla visualmente como la extensión de su vida cotidiana y social. En el periodo comentado, Santiago experimentaba los signos crecientes de la modernización en el plano social, a pesar de la fuerza compacta de uno de los catolicismos más conservadores de Sudamérica y de una clase terrateniente estricta en la observancia de "prestigios nobiliarios". Algunos factores que contribuyeron a introducir cambios progresivos - muchas veces no deseados- fueron la migración de las familias patricias desde las provincias que ampliaron la composición media de la ciudad, el crecimiento del aparato burocrático y la influencia de una inmigración extranjera que introdujo nuevos rituales, modas y formas de secularización.

La mirada tiene una prerrogativa nueva: unir lo simbólico a la materialidad del tiempo filmado. El movimiento-técnico del cine da al nacionalismo una fuerza dramatúrgica inédita gracias a la capacidad de dirigir la memoria y el destino como los escenarios del sujeto moderno. Los primeros filmes nos permiten asistir a la idea de su propio rodaje - pensando en Godard y $L a$ Chinoise- es decir, el momento en que la nación imaginándose se pone en escena. Por ello, la imagen cinematográfica no traduce una política literal, al contrario, en el efímero registro por ejemplo, de las carreras de Viña del Mar, se compaginan la cotidianeidad de un evento masivo que nos enseña la organización espacial del espectáculo y la anacronía patrimonial, heredada 
por el presente, que la observa como índice. O bien, las múltiples fotografías de damas en poses ocasionales no describen la naturalidad de los cuerpos, sino la fisonomía material del poder allí investido de belleza y orden ideal. Se trata de saturar a la imagen con formas alegóricas y realistas para que nada desvíe la representación de su utilidad confesional.

No pretendemos reiterar la idea del cine, la fotografía y sus fragmentos como reflejos de una retórica nacionalista ya predeterminada. La operación iconográfica -incluso en los detalles menores- despliega un montaje de frases, actos, eslogans, vestidos, gestos, etc. que elabora una poética barrocomoderna de imágenes donde el cuerpo, el paisaje y la identidad documentan la condición narrativa y el efecto significante. Hacia mediados de siglo este proceso ha sido integrado y modificado por nuevas configuraciones de lo nacional que incluyen trabajos del estereotipo y la crítica. El cine chileno, entonces, no reproduce un ethos, más bien elabora las fábulas cinematográficas de su necesidad. El realismo fundacional del que hemos hablado en párrafos anteriores propone una hipótesis y un método de análisis: la nación se hace visual y estudiar su configuración fílmica significa entender las relaciones entre mirada, imagen y poder. No hay continuidad exacta entre visualidad y nacionalismo en el caso chileno, eso solo lo imagina la propaganda, hay múltiples citas que dialogan fracasando en el intento de una totalidad. Así, la nación no tiene un texto previo a escenificar en imágenes y el cine o la fotografía no son técnicas representacionales cayendo en la usura del libreto oficial. El estudio de fotografías y filmes nos puede decir mucho sobre las memorias del poder, sus fantasías y descalces, pues la representación que el Estado hace de sí mismo cuando dialoga o enfrenta a la sociedad se manifiesta, estéticamente, a través del trabajo que consiste en confirmar la trascendencia, exigir aclamación y vencer la incertidumbre. Hay en las imágenes un recorte histórico, cierta voluntad visual de ordenar el contexto con los poderes técnicos de la fotografía y el cinematógrafo cuya escritura de luz atiende la ilusión integradora del Estado; la cotidianeidad muda de lo privado; la exaltación museística de la identidad; el orgullo clasista de la diferencia y la romantización disciplinaria del pueblo.

\section{BIBLIOGRAFÍA}

Alvarado, Margarita et al. Mapuche. Fotografías siglos XIX y XX. Construcción y montaje de un imaginario. Santiago: Pehuén, 2001. 
Andermann, Jens \& William Rowe. Images of power: iconography, culture and state in Latin America. Toronto: Berghahn Books, 2005.

Ariza, María. Retratos del príncipe cristiano. De Erasmo a Quevedo. Córdoba: Ediciones de la Universidad de Córdoba, 1995.

Báez, Christián et al. Imágenes de la Identidad. Santiago: Tajamar, 2009.

Bisama, Antonio. Álbum Gráfico Militar de Chile. Campaña del Pacífico. Santiago: Editorial Universo, 1909.

Barros, Luis y Ximena Vergara. El modo de ser aristocrático. El caso de la oligarquía chilena hacia el 1900. Santiago: Ediciones Aconcagua, 1978.

Correa, Sofía et al. Historia del siglo XX chileno. Santiago: Sudamericana, 2001.

Crary, Jonathan. Suspensiones de la percepción. Atención, espectáculo y cultura moderna. Madrid: Editores Akal, 2008.

De la Flor, Fernando. Imago. La cultura visual y figurativa del barroco. Editorial Abada, España, 2009.

De Sousa, Boaventura. Refundación del Estado en América Latina. Perspectivas desde una epistemología del sur. Bolivia: Plural Ediciones, 2010.

Echeverría, Bolívar. La Modernidad de lo barroco. México D.F.: Ediciones Unam, 2000.

Eliash, Humberto y Manuel Moreno. Arquitectura y Modernidad en Chile 1925-1965. Ediciones Universidad Católica, Santiago, 1989.

Etienvre Pierre. "La métaphore du jeu et la vie politique de l'image au modele". En W. Euchner, F. Rigotti y P. Schiera: "Il Podere delle immagini. La metáfora política in prospectiva storica”. Bologna: Il Mulino, 1998.

Espinoza, Vicente. Para una historia de los pobres de la ciudad. Santiago: Ediciones Sur, 1987.

Esposito, Roberto. Communitas. Origen y destino de la comunidad. Amorrortu Editores, Buenos Aires, 2007.

Fernández, Enrique. Estado y Sociedad en Chile, 1891-1931. El estado excluyente, la lógica estatal oligárquica y la formación de la sociedad. Santiago: Editorial Lom, 2003.

Freedberg, David. El poder de las imágenes. Madrid: Editorial Alianza, 1989.

García Canclini, Néstor. Culturas Hibridas. México: Grijalbo, 1990.

Góngora, Mario. Ensayo histórico sobre la noción de Estado en Chile en los siglos XIXY XX. Santiago: Ediciones La Ciudad, 1981.

González García, Jesús. Metáforas del poder. Madrid: Editorial Alianza, 1998.

Grez, Sergio. La cuestión social en Chile. Ideas y debates precursores (1804-1902). Santiago: Ediciones Dibam, 1995.

Gruzinski, Serge. El Pensamiento Mestizo. México: Editorial Páidos, 2007.

Jay, Martin. Campos de Fuerza. Madrid: Editorial Paidós, 2004.

Jocelyn-Holt, Alfredo. El peso de la noche. Nuestra frágil fortaleza histórica. Santiago: Editorial Planeta, 1999.

Jara, Eliana. Cine mudo chileno. Santiago: Ediciones Los Héroes, 1994. 
Koselleck, Reinhart. Aceleración, Prognosis y Secularización. Valencia: Editorial Pre-Textos, 2003.

Larraín, Jorge. Identidad Chilena. Santiago: Editorial Lom, 2001.

Majluf, Natalia. "De cómo reemplazar a un rey: retrato, visualidad y poder en la crisis de la independencia (1808-1830)". Revista Histórica XXXVII.1 (2013): 73-108. En: http:// revistas.pucp.edu.pe/index.php/historica/article/view/7642/7892

Maravall, J.A. La cultura del barroco. Madrid: Editorial Ariel, 1975.

Mandoki, Katya. La construcción estética del Estado y la identidad nacional. Prosaica III. México: Conaculta-Siglo XXI, 2007.

Marin, Louis. Portrait of the King. Trad. de Martha Houle. University of Minnesota Press, 1988.

Martínez, Boris y Manuel Salgado. Olivares Valdivia, Fotografía y sociedad en Copiapó 1909-1948. Santiago: Pehuén Editores, 2006.

Navarrete, José Antonio. "Las buenas maneras. Fotografía y sujeto burgués en América Latina (Siglo XIX)”. Revista Aisthesis No35 (2002).

Ossa, Carlos (coautor). Historia del Cine Chileno. Santiago: Editorial Quimantú, 1971.

Ossandón, Carlos. La Sociedad de los Artistas. Santiago: Editorial Palidonia, 2008.

Pinto, Julio y Verónica Valdivia. ¿Chilenos todos? La construcción social de la nación (1810-1840). Santiago: Lom, 2009.

Riera, Francisca. “Jorge Opazo. La cámara y el poder”. Jorge Opazo: retrato fotográfico, imagen y poder. Eds. Margarita Alvarado, Mariana Mattheus y Carla Möller. Santiago: Pehuén, 2007.

Rinke, Stefan. Cultura de Masas, Reforma y Nacionalismo en Chile, 1910-1931. Santiago: Ediciones Dibam, 2002.

Rodríguez, Hernán. Fotógrafos en Chile durante el Siglo XIX. Santiago: Centro Nacional del Patrimonio Fotográfico, 2001.

Salazar, Gabriel y Julio Pinto. Historia Contemporánea de Chile T. I y II. Santiago: Editorial Lom, 1999.

Santa Cruz, Eduardo. Las Escuelas de la Identidad. Santiago: Editorial Lom, 2007.

Stephan, Beatriz. Las Galerías del Progreso. Beatriz Viterbo Editor, Argentina, 2006.

Stuven, Ana María. La seducción del poder. Las elites y la construcción de Chile en las polémicas culturales y políticas del siglo XIX. Santiago: Ediciones Universidad Católica, 2000.

Zaldívar, Trinidad y Sánchez, Macarena. "Símbolos, emblemas y ritos en la construcción de la nación. La fiesta cívica republicana: Chile 1810-1830”, en Cid, Gabriel y San Francisco, Alejandro. Nación y Nacionalismo en Chile. Siglo XIX. Santiago de Chile: Ediciones del Centro de Estudios Bicentenario, 2009. 